\title{
The Socio-economic Impact of Climate Change on the Coastal Zone of the Gambia
}

\author{
Joshua Amuzu,", Bubu P. Jallow ${ }^{2}$, Amos T. Kabo-Bah ${ }^{3}$, Sidat Yaffa ${ }^{4}$ \\ ${ }^{1}$ West African Science Service Center on Climate Change and Adapted Land Use (WASCAL) Headquarters, CSIR Office Complex, \\ Airport Residential Area, Ghana \\ ${ }^{2}$ Department of Water Resources, 7 Marina Parade, the Gambia \\ ${ }^{3}$ Department of Energy and Environmental Engineering, University of Energy and Natural Resources, Ghana \\ ${ }^{4}$ University of the Gambia, Farafenni Campus, North Bank Region, the Gambia
}

Copyright $\odot 2018$ by authors, all rights reserved. Authors agree this article remains permanently open access under the terms of the Creative Commons Attribution License 4.0 International License

\begin{abstract}
Coastal systems are predominantly delicate to three key drivers related to Climate Change (CC): Sea Level Rise (SLR); ocean temperature and; ocean acidity. This study focused on the impacts realized from SLR. These variables are anticipated to increase with significant threats to the populace and structures of social, cultural or economic importance along Coastal Zones (CZ). This study seeks to: characterize the trend of annual rainfall, minimum and maximum temperatures from 1986- 2016; estimate the land at-risk of being lost to inundation under a $1 \mathrm{~m}$ SLR scenario and the estimation of the rate of annual land loss for each coastal cell in The Gambia. This study estimates the monetary value of land to be lost and the population at risk of $\mathrm{CC}$ impacts in the study area. The results of the study reveal mean annual rainfall increased at a rate of $0.237 \mathrm{~mm}$ per annum over the $\mathrm{CZ}$. The annual minimum temperature showed a decreasing trend of $0.026^{\circ} \mathrm{C}$ while the maximum temperature showed an increasing trend of $0.028^{\circ} \mathrm{C}$ annually. By the end of this century, under a $1 \mathrm{~m}$ SLR scenario, the total land to be lost due to inundation is $\sim 12.46 \mathrm{~km}^{2}$ (1,246 ha) with a corresponding economic loss of $\sim$ US $\$ 788$ Million (GMD37 Billion) over the CZ. This land loss is predicted to occur at an approximate rate of $6 \mathrm{~m}$ annually along the CZ of The Gambia. Over 15,560 people per $\mathrm{km}^{2}$ of land are estimated to be at risk of coastal flooding events in the study area.
\end{abstract}

Keywords Climate Change, Socio-economic Impact, Coastal Zone, Coastal Erosion, Bruun Rule, Sea Level Rise, Vulnerability Assessment, Adaptation, The Gambia

\section{Introduction}

The oceans cover over $70 \%$ of the earth's surface and play an important role in regulating the earth's climate by serving as a major sink of carbon dioxide $\left(\mathrm{CO}_{2}\right)$ from the atmosphere. Since the mid-20th century, there has been $95 \%$ scientific certainty that human activity increases concentrations of Green House Gases (GHGs) in the atmosphere, and has been the dominant cause of the observed warming and other climate change impacts [1] This in effect affects the ocean's ability to provide regulatory services efficiently. Coastal systems are predominantly delicate to three key drivers related to Climate Change (CC): sea level rise; ocean temperature and; ocean acidity. This study focuses on the impacts realized from Sea Level Rise (SLR). Sea Level Rise largely occurs due to melting of glaciers and ice sheet's mass of Arctic and Antarctic regions, and thermal expansion due to rise in temperature [1].

The global mean surface temperature change for the period $2016-2035$ is likely to rise by $0.3-0.7^{\circ} \mathrm{C}$ [1]. This finding implies there will be a further warming of the ocean surface with the resultant expansion of its waters exacerbating SLR occurrence at the local level. Past trends revealed a likely decrease in average annual rainfall in most parts of West Africa, with an observed drop in average annual rainfall of approximately $25-50 \mathrm{~mm}$ each decade from 1951-2010 [1]. Reduction in rainfall will reduce sediment delivery to the oceans from sources like rivers and streams [7-9]. This will deprive the shoreline of sediment, likely to exacerbate the rate of coastal erosion and sediment withdrawal from shorelines. The continued acceleration in the decline of polar ice sheet mass from the Arctic and Antarctic regions coupled with melting glaciers in present times raises the possibility of future SLR of over $1 \mathrm{~m}$ by 2100 [1]. These impacts elevate the anticipated risk of land loss due to inundation raising concerns for most coastal countries in Sub-Sahara Africa.

The Gambia, for instance, is cited among the ten main nations debilitated by SLR, due to its low elevation coastal 
zone [10-12]. It is predicted that about $92 \mathrm{~km}^{2}$ of land in the Coastal Zone (CZ) of The Gambia will be submerged and inundated due to only $1 \mathrm{~m}$ SLR [12]. Under this scenario, The Gambia will lose its capital city, Banjul. The Gambia, like other coastal nations in West Africa, has its ports and significant tourism and infrastructure of economic and social importance exposed to SLR impacts within the coastal zone. These areas also have a dense population with climate change threats to humans [13]. The increment in wave activity combined with poor urban design and sand quarrying for developmental initiatives has resulted in the loss of land along the southern coastline of The Gambia. These joint actions have prompted the loss of vital social and cultural sites, infrastructure and nesting grounds for turtles and transient birds [12]. In addressing this issue, a notable action the Government of The Gambia took in 2004 is the beach nourishment program along the coastline of The Gambia. This was aimed at reclaiming lost land in the quest to boost tourism and protect important structures from being lost. However, concerns have been raised about whether this adaptation action has protected the coastline, as the majority of these has been lost again [14]. There is the need to appraise further options and arrive at a more effective line of action to take to elude maladaptation in the coastal zone of The Gambia.

In urban areas, climate change is anticipated to increase risks for people, properties, economies and ecosystems [1]. The population and assets exposed to coastal threats and human forces on coastal ecosystems will increase significantly in the coming decades due to population growth, economic development, and urbanization. To support this claim, UN-HABITAT [15] reports that over $25 \%$ of Africa's population live within $100 \mathrm{~km}$ of the coastal zone and over $50 \%$ of Africa's total population live in low-elevation coastal zones (LECZ). This value accounts for $11.5 \%$ of the total urban population of the African continent of which The Gambia is no exception. With a mean surge in ocean levels of just $0.38 \mathrm{~m}$ consolidated with populace growth situations, it is evaluated that the normal number of individuals around the entire coast of Africa at risk of floods could rise from 1 Million per year in 1990 to 70 Million per year in the 2080s [16]. And with a $43 \mathrm{~cm}$ rise in sea levels, over 10 Million Africans will be compelled to migrate from 2000 to 2100 , the aggregated economic cost of damaged assets will be US $\$ 38$ Billion per year in the same period [17]. However, with apt climate change adaptation measures in place, these effects can be decreased considerably, to a yearly cost of US\$2.2 Billion in most African countries [17].

For the 21st century, the benefits of defending against increased coastal flooding and inundation due to SLR and coastal erosion at the global to local scale are larger than the social and economic costs of inaction [1]. The study and putting into practice coastal adaptation measures have increased more considerably in developed countries than in developing countries toward climate-resilient and sustainable coasts [1]. These support the need to undertake an in-depth analysis of the socio-economic impact of climate change on the coastal zone of The Gambia to fill this research gap. Thus, the motivation for this study.

Specifically, this study seeks to: characterize the trend of annual rainfall, minimum and maximum temperatures over the coastal zone of The Gambia from 1986- 2016. The findings from the trend analysis of minimum and maximum temperature over the study area will reveal the rate at which temperature is increasing relative to the rate of cooling. This gives a background to reveal the possibility of thermal expansion which could account for SLR incidence in the study area. The results of the trend analysis of mean annual rainfall will aid in revealing the status of sediment recharge or withdrawal from the coastline. This information will aid farmers, fisherfolk, tourists and other stakeholders in the adoption of more operational coping and adaptation strategies in the face of climate change and its variability in the study area.

The direct inundation concept is employed in estimating the total land at-risk of being lost to inundation under a $1 \mathrm{~m}$ SLR scenario by the end of this century. The Bruun Rule is used in estimating the rate at which this land will be lost to coastal erosion annually over a 100 -year time scale for each coastal cell in the study area. This study further estimates the monetary value of land to be lost and the population at risk of CC impacts in the study area. This information will aid in enlightening the public on the coastal areas that are more vulnerable to coastal erosion than others to help in making decisions that are more informed in the acquisition of land, the establishment of settlements and infrastructure of social and economic importance along the coastal zone. The findings will further draw the attention of other key players in Government institutions on areas to put up key economic structures and infrastructural developments to avert exerting stress on coastal systems to enhance climate-resilience in the study area. The study will also aid in increasing revenue from tourism. As tourism is the largest foreign exchange earner and the second largest contributor to the GDP of The Gambia- 16\% was recorded in the year 2016 [46].

\section{Materials and Methods}

\subsection{Characterizing the Trend of Annual Rainfall, Minimum, and Maximum Temperature}

Trend analysis is used in achieving this objective of the study. To describe the trend of annual rainfall, annual minimum and maximum temperature in the coastal zone of The Gambia from 1986- 2016, a line graph is drawn to show the trend of Rainfall (in mm), annual minimum and 
maximum temperature $\left(\right.$ in ${ }^{\circ} \mathrm{C}$ ) respectively. The growth rate over the period can be estimated using the simple linear regression model below (1);

$$
\mathrm{Y}_{\mathrm{t}}=\beta_{\mathrm{o}}+\beta_{\mathrm{i}} \mathrm{T}+\mathrm{e}_{\mathrm{i}} \mathrm{Y}_{\mathrm{t}}=\beta_{0}+\beta_{\mathrm{i}} \mathrm{T}+\mathrm{e}_{\mathrm{i}} \mathrm{Y}_{\mathrm{t}}=\beta_{\mathrm{o}}+\beta_{\mathrm{i}} \mathrm{T}+\mathrm{e}_{\mathrm{i}}
$$

Where: $Y_{\mathrm{t}}=$ Annual Rainfall (in $\mathrm{mm}$ ) or Minimum / Maximum Temperature (in ${ }^{\circ} \mathrm{C}$ ); $\beta_{\mathrm{o}}=$ Intercept; $\beta_{\mathrm{i}}=$ Trend; $\mathrm{T}=$ Time (1986- 2016); $\mathrm{e}_{\mathrm{i}}=$ Error term.

\subsection{Estimation of Land Loss Due to Inundation and Future Land Loss Rate Due to Coastal Erosion}

The direct inundation concept is applied to estimate the land loss due to Inundation. Using the contoured topographic map of the coastal strip of The Gambia, the area of land that falls within the $1 \mathrm{~m}$ contour line in the study area is shaded. A transparency paper with a graduated grid (mess) of $1 \mathrm{~cm}$ by $1 \mathrm{~cm}$ area is placed on the shaded areas of the map. The number of the graduated grid that falls within the shaded area is counted and conversions made with the scale of the map. The total area recorded gives the area to be inundated under a $1 \mathrm{~m}$ SLR scenario.

The mathematical expression of Bruun Rule [18] is used to estimate the future land loss rate due to coastal erosion under varied IPCC scenarios. Jallow et al [12] used the Aerial Videotape-Assisted Vulnerability Analysis (AVVA) in the delineation of the study area into nine coastal cells. The Bruun rule is then applied to each coastal cell in the coastal zone, this is given as (2);

$$
\mathrm{R}=\mathrm{G} \times \mathrm{S}\left[\mathrm{W} /\left(\mathrm{H}+\mathrm{d}^{*}\right)\right] \mathrm{R}=\mathrm{G} \times \mathrm{S}\left[\frac{\mathrm{W}}{\mathrm{H}+\mathrm{d}^{*}}\right]
$$

Where: $\mathrm{R}=$ Shoreline Retreat (coastal erosion) due to SLR; $\mathrm{G}=$ Overfill ratio of the materials being eroded; $\mathrm{H}=$ Dune/Cliff Height; $\mathrm{d}^{*}=$ Depth of closure; $\mathrm{W}=$ Width of the active profile. This ranges from the dune to the depth of closure; $\mathrm{S}=$ Projected SLR Scenarios.

In the case of The Gambia, the value, $G$ is assumed to be a uniform value of 1.0 as the coastal zone of The Gambia is mainly characterized by fine sand erodible materials [12]. The depth of closure, $\mathrm{d}^{*}$ is the most difficult variable to estimate, as it largely varies with timescales $[12,19]$. The longer the time under study, the larger the value of the depth of closure with resultant positive impact on the rate of coastal erosion from SLR. To get the depth of closure over the 100-year timescale, a low and a high estimate of this variable is created, $d_{L 1}$ and $d_{L 100}$ respectively. The low estimate is determined by field measurement using the bathymetric map of The Gambia along the respective cells that make up the coastal zone of The Gambia. Nicholls and Leatherman [20] developed a relation for estimating the high estimate, $\mathrm{d}_{L 100}$ of the depth of closure over 100 years provided the low estimate, $d_{L 1}$ is given; this is given as (3). The bathymetric map is further used in the estimation of the width of the active beach profile. The coastline is divided into segments based on the width and cliff height similarities, and the Bruun Rule is applied for estimations of the annual rates of imminent coastal erosion. Fig. 1 illustrates the parameters integrated into the Bruun rule to estimate the future erosion rate due to SLR.

$$
\mathrm{D}_{L 100}=1.75 \times \mathrm{d}_{L 1} \mathrm{~d}_{\mathrm{L}_{100}}=1.75 \times \mathrm{d}_{\mathrm{L}_{1}}
$$

The Bruun Rule is frequently used as a quantifiable way to predict the shoreline to be lost under given ocean level ascent on straight sandy shores [21-23]. Other studies that have used Bruun rule in its estimations of threats of SLR are Corbella and Stretch [24] in South Africa, where 4 to 18 beach profiles were examined; Aagaard and Sorensen [25] similarly used this methodology to examine the coastlines of Denmark. Jallow et al [12] estimated the vulnerability of the coastal zone of The Gambia and Abidjan using this rule.

The notion, proposed by Bruun [18], states that a marine shoreline maintains an equilibrium profile with the depth and slope determined by the current and wave regime. This basic model illustrates that the shoreline profile is an illustrative capacity whose parameters are controlled by the mean water level and the sediment estimate. All things being equal, a typical coast will adjust to ocean level ascent naturally [18]. The coast must keep pace with ocean level ascent, raising its profile with regards to the ocean level. To do this, a residue budget must be established. In synopsis, when SLR occurs, the shoreline withdraws and another proportional profile is created at the new shoreline position by the movement of residue to further areas (Fig. 1). The beach profile is moved to an upward and landward location [18]. Although the Bruun Rule has been used extensively in research, it is not suitable for countries with rocky beaches and assumes that coastal erosion is wholly due to SLR, excluding other factors.

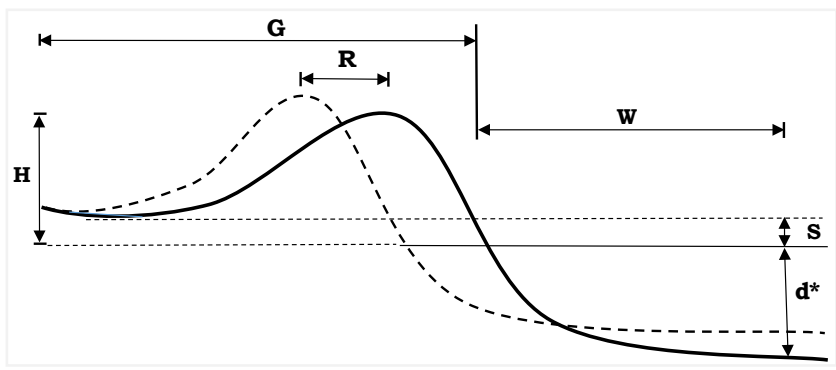

Figure 1. Illustration of the parameters of the Bruun Rule

\subsection{Estimating Population at Risk of Coastal Flooding}

The IPCC mathematical definition of Population at Risk is used in estimating the number of people exposed to potential coastal erosion and flooding impacts in each coastal cell of the study area [1], this is given as (4).

$$
\text { Population at Risk }=\mathrm{PD} \times \mathrm{PC}
$$


Where: PD = Population Density; $\mathrm{PC}=$ Probability of Coastal Flooding in each coastal cell.

\subsection{Type and Sources of Data for the Study and Description of the Study Area}

The data sourced from the Department of Lands and Surveys of The Gambia is the Contoured Topographic Map of the Coastal strip of The Gambia. This data gives the conditions of the coastal zone in recent times, from which measurements like dune height and the active beach profile are obtained. The scale of this map used is 1: 10,000. Ground-Truthing with Global Positioning System (GPS) is undertaken to cross-reference the values obtained from the maps with field measurements in the study area. The data sourced from The Gambia Ports Authority is the bathymetric map of The Gambia. This showed the depths of the sea along the coastal strip and the River Gambia estuary in the year under review. The data sourced from the Department of Water Resources includes meteorological time series data from 1986- 2016 on Annual Rainfall; Minimum and Maximum Temperature over the study area. This data is used in characterizing the trend of the key climatic variables over the past 30-years in the study area. Finally, the data sourced from The Gambia Bureau of Statistics (GBoS) were population statistics for each coastal area under the study. This is used in the estimation of the population at risk of coastal flooding in the study area.

The Gambia, lying between latitudes 13 and $14^{0}$ North and longitudes 17 and $12^{0}$ West, is the smallest nation in mainland Africa. It has an aggregate territory of around $11,300 \mathrm{~km}^{2}$ of which $10,000 \mathrm{~km}^{2}$ is land and $1,300 \mathrm{~km}^{2}$ is water [10]. The Gambia has $80 \mathrm{~km}$ of open coastline circumscribing the Atlantic Ocean and over $200 \mathrm{~km}$ of protected coastline along the River Gambia. The open coast is characterized by low-inclination sandy shorelines. Broad mangrove frameworks of over 66,900 ha and mud flats overwhelm the shielded coast [12]. The coastal zone of The Gambia out ranges $80 \mathrm{~km}$ from Buniadu Point and the Karenti Bolong in the North, to the mouth of the Allahein River in the South (Fig. 2). The coastal zone of The Gambia is alienated into nine coastal cells based on geomorphological characteristics (Fig. 2).

\section{The Coastal Zone of The Gambia}

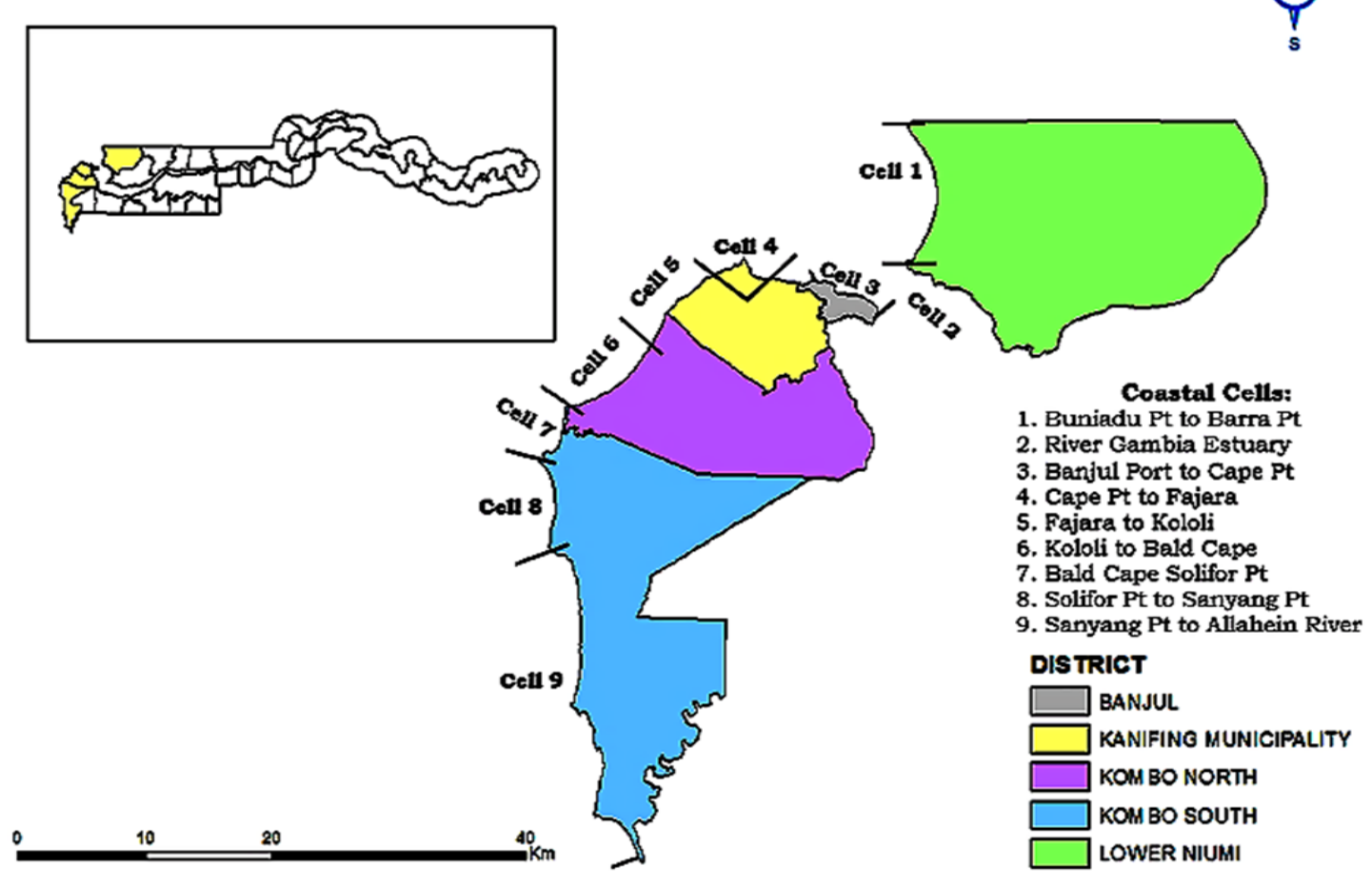

Figure 2. Map of the study area; showing the $\mathrm{CZ}$ of The Gambia. 


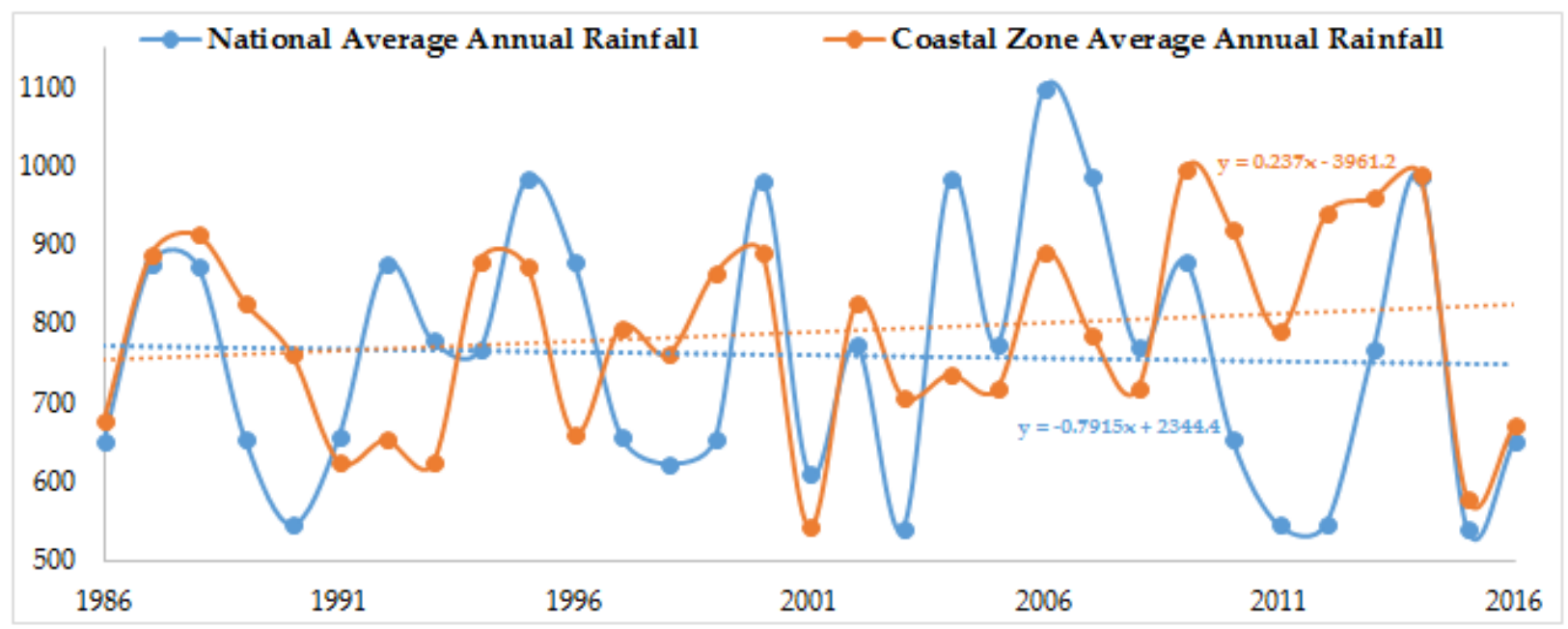

Figure 3. The trend of Annual Rainfall from 1986- 2016 (Annual Rainfall in MM against the number of years). Source: Author, 2017

\section{Results and Discussion}

\subsection{Trend Analysis of Annual Rainfall, Minimum and Maximum Temperature}

Fig. 3 shows the trend of annual rainfall over the whole Gambia and the coastal zone from 1986 - 2016. From the graph, the annual rainfall over the past 30 years has been decreasing by $0.79 \mathrm{~mm}$ annually over the whole country (Table 1). These values were obtained from analysis of secondary data from all the 10 meteorological stations of The Gambia. This recorded value is much lower than the $3 \mathrm{~mm}$ decrease in annual rainfall amount reported by Urquhart [26] from 1950 to 2000 in The Gambia. This might result from improvements in meteorological equipment in recent times giving more precision in measurement relative to the past fifty years. The decrease in rainfall over the whole Gambia has become evident as the length of the rainy season is decreasing $[10,11]$. The decrease in the annual rainfall over the study area agrees to IPCC AR5 [1] report with other studies supporting this assertion [27-30]. However, the $0.79 \mathrm{~mm}$ annual decline in rainfall is much higher in value, in contrast to the $15 \%$ value observed over the West Africa sub-region [1]. Since The Gambia falls within the Sudan-Savanna zone of Africa it is characterized by relatively low rainfall amounts, a short wet season and a long dry season with six to seven months without active rains, this may account for the observed variation from the values obtained for the whole West Africa sub-region [11, 31, 32]. The observed trend in The Gambia may be because of the decrease in the number of rain-generating synoptic circumstances rather than a decline in the rainfall intensity received annually $[31,33]$. Although there has been a steady decrease in the rainfall received over the past 30 years, there have been observed increases in the last decade like; 2006, 2009, 2012 and 2014 where meteorological drought was recorded sometime. The decrease in annual rainfall amounts has implications for small-scale farming, artisanal fisheries and livestock raising activities in The Gambia. Most agricultural activities in The Gambia are rainfall-dependent, a decrease in its amounts largely constrains farming activities with resultant impact on the nation's food security needs [32]. In the year 2011 for instance, The Gambia experienced a meteorological drought; this led to crop failures with resultant food security concerns. This informed the Government of The Gambia's decision to officially declare a nationwide drought emergency in the year 2012. The lives and livelihood of people were affected as over $40 \%$ of the populace encountered hunger situations leading to humanitarian appeals as crops failed over one-third of production compared with 2010 [28,34].

Conversely, the annual rainfall over the coastal zone of The Gambia alone revealed a positive trend of $0.237 \mathrm{~mm}$ over the past 30 years 1986 - 2016 (Table 2). These values were obtained from analysis of secondary data from five meteorological stations (Banjul, Yundum, Sibanor, Kerewan and Jenoi) within the coastal zone of The Gambia. Relatively higher humidity and lower temperatures characterize coastal zones in comparison with areas hinterland $[1,35]$. This may have led to the observed positive trend in rainfall amount received annually. This trend has been observed in other coastal areas of Africa [36]. For instance, Mohamed [35] accounts that the Mediterranean coastal zone of Egypt experienced a consecutive increase in annual rainfall throughout the last 30 years with a $0.76 \mathrm{~mm}$ annual trend over the area. A similar positive trend of $3 \mathrm{~mm}$ is observed in the annual rainfall amount over the western coastal zone of Egypt [35]. The islands of the North- East part of Sri Lanka likewise recorded a positive annual trend over the 30 year period under review [37]. A similar positive trend in the annual rainfall amount is observed in Morocco and Tunisia coastal areas [38]. The observed increase in the mean annual rainfall in the coastal zone of The Gambia is likely to increase the delivery of sediments to the coastline 
from run-off into streams and other tributaries. This has positive implications for the natural restoration of some areas in the $\mathrm{CZ}$ of The Gambia.

Table 1. Estimated Growth Model of Annual Rainfall of the whole Gambia from 1986- 2016

\begin{tabular}{|c|c|c|}
\hline Variable & Coefficient & Standard Error \\
\hline Trend (T) & -0.792 & 1.21 \\
\hline Intercept (C) & 2344.41 & 1121.43 \\
\hline R- Square & 0.67 & F-statistics 0.057 \\
\hline Adjusted R-Square & 0.42 & Prob(F-statistics) 0.813 \\
\hline
\end{tabular}

Table 2. Estimated Growth Model of Annual Rainfall of the $\mathrm{CZ}$ of The Gambia 1986- 2016

\begin{tabular}{|c|c|c|}
\hline Variable & Coefficient & Standard Error \\
\hline Trend $(\mathrm{T})$ & 0.237 & 1.21 \\
\hline Intercept $(\mathrm{C})$ & -3961.21 & 1121.43 \\
\hline R- Square & 0.78 & F-statistics 0.905 \\
\hline Adjusted R-Square & 0.53 & Prob (F-statistics) 0.349 \\
\hline
\end{tabular}

Fig. 4 gives the trend of annual minimum and maximum temperatures from 1986 - 2016 over the coastal zone of The Gambia. These values were obtained from analysis of secondary data from five meteorological stations (Banjul, Yundum, Sibanor, Kerewan and Jenoi) within the coastal zone of The Gambia. The annual minimum temperature over the past 30 years showed a decreasing trend rate of $0.026^{\circ} \mathrm{C}$ each year over the study area (Table 3 ).

The yearly maximum temperature showed an increasing trend rate of $0.028^{\circ} \mathrm{C}$ in the coastal zone of The Gambia over the past three decades (Table 4). The temperature value, $28.2^{\circ} \mathrm{C}$ has been the highest recorded since the year
1947 in the history of The Gambia, with changes in this temperature record over the coastal zone in recent years [11, 39]. This observed trend in the study area agrees with IPCC [1], Lima and Wethey [40] studies.

The observed increase in the annual maximum temperature is higher $(0.0276)$ than the decreases in the annual minimum temperature $(0.0255)$ in the coastal zone of The Gambia. This may have contributed to more warming than cooling events in the coastal zone of The Gambia over the past 30 years. This may account for the observed SLR in the study area due to thermal expansion of the ocean surface. If this trend persists over the coming years, it may exacerbate the occurrence of SLR in the study area in the medium to long-term.

Table 3. Estimated Growth Model of Annual Minimum Temperature of the coastal zone of The Gambia from 1986- 2016

\begin{tabular}{|c|c|c|}
\hline Variable & Coefficient & Standard Error \\
\hline Trend (T) & -0.026 & 0.01 \\
\hline Intercept (C) & 71.75 & 11.22 \\
\hline R- Square & 0.62 & F-statistics 6.35 \\
\hline Adjusted R-Square & 0.51 & Prob (F-statistics) 0.001 \\
\hline
\end{tabular}

Table 4. Estimated Growth Model of Annual Maximum Temperature of the coastal zone of The Gambia from 1986- 2016

\begin{tabular}{|c|c|c|}
\hline Variable & Coefficient & Standard Error \\
\hline Trend (T) & 0.028 & 0.01 \\
\hline Intercept $(\mathrm{C})$ & -20.91 & 12.59 \\
\hline R- Square & 0.54 & F-statistics 8.067 \\
\hline Adjusted R-Square & 0.41 & $\begin{array}{c}\text { Prob (F-statistics) } \\
0.002\end{array}$ \\
\hline
\end{tabular}

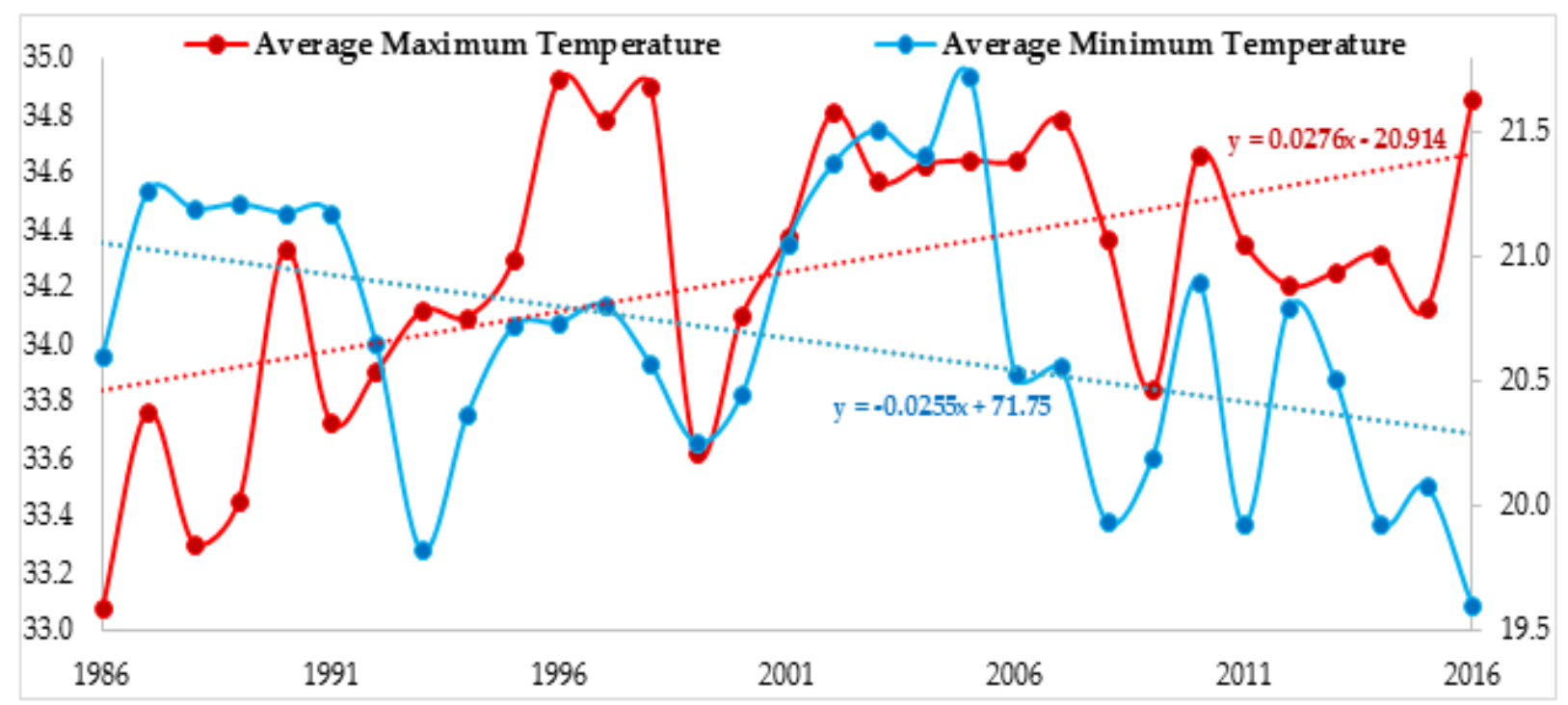

Figure 4. The trend of Annual Minimum and Maximum Temperatures $\left(\right.$ in $\left.{ }^{\circ} \mathrm{C}\right)$ of the $\mathrm{CZ}$ from 1986- 2016. Source: Author, 2017 


\subsection{Estimation of Land Loss Due to Inundation}

Table 5 presents the land to be lost due to inundation from a $1 \mathrm{~m}$ rise in sea levels. It also presents the economic value of land to be lost in Gambian Dalasi (GMD) and its US dollar equivalent. The result of the study reveals that the total land to be lost to inundation is $12.46 \mathrm{~km}^{2}(1,246 \mathrm{ha})$ with a corresponding economic loss of $\sim$ US $\$ 788$ Million (GMD 37 Billion) estimated at the November, 2017 exchange rate of US \$1 equivalent to GMD 47.45 (Table $5)$.

Detailed analysis of the topographic and bathymetric maps of The Gambia reveals areas of the Bald Cape to Solifor Point (coastal cell 7) has the largest area falling below the $1 \mathrm{~m}$ contour line $\left(2.79 \mathrm{~km}^{2}\right)$ hence, having the highest area at risk of inundation with an economic loss of US \$176.4 Million. This is followed by the area from Banjul to Cape Point (coastal cell 3) and from Sanyang Point to Allahein River (Coastal cell 9); this corresponds to a land area of $2.24 \mathrm{~km}^{2}$ and $2.16 \mathrm{~km}^{2}$ respectively. The coastal cell 9, for instance, is an area where most legal and illegal sand mining operations take place in The Gambia. With the rate of land loss due to this anthropogenic forcing, it is anticipated that the rates estimated in this study may occur sooner than later.

However, the area from Fajara to Kololi (Coastal cell 5) has most of its land area above the $1 \mathrm{~m}$ sea level corresponding to the area having the least land loss to inundation owing to SLR. This area houses the highest point on the coast, 11 meters above mean sea level [42]. Cliffs and higher grounds $1 \mathrm{~m}$ above mean sea level characterize this area accounting for the least rate of land loss from inundation. The description of each coastal cell with pictorial proves showing structures at risk of threats from SLR and suggested adaptation measures that can be employed are given further below.

Table 5. Land loss due to Inundation from $1 \mathrm{~m}$ Sea Level Rise

\begin{tabular}{|c|c|c|c|}
\hline Coastal Cells & $\mathbf{K m}^{2}$ & $\begin{array}{c}\text { Million } \\
\text { Dalasi }\end{array}$ & $\begin{array}{c}\text { Million } \\
\text { USD }\end{array}$ \\
\hline $\begin{array}{c}\text { 1 (Buniadu- Barra } \\
\text { Point) }\end{array}$ & 0.8 & 2,430 & 51 \\
\hline $\begin{array}{c}\text { 2 (River Gambia } \\
\text { Estuary) }\end{array}$ & - & - & - \\
\hline $\begin{array}{c}\text { 3 (Banjul Port- Cape } \\
\text { Point) }\end{array}$ & 2.24 & 6,720 & 142 \\
\hline 4 (Cape Point- Fajara) & 1 & 3,000 & 63 \\
\hline 5 (Fajara- Kololi) & 0.62 & 1,860 & 39 \\
\hline 6 (Kololi- Bald Cape) & 0.88 & 2,640 & 56 \\
\hline 7 (Bald Cape- Solifor \\
\hline Point) & 2.79 & 8,370 & 176 \\
\hline $\begin{array}{c}\text { ( Solifor Point- } \\
\text { Sanyang Point) }\end{array}$ & 1.96 & 5,880 & 124 \\
\hline 9 (Sanyang Point- \\
Allahein River) & 2.16 & 6,480 & 137 \\
\hline Total & $\mathbf{1 2 . 4 6}$ & $\mathbf{3 7 , 3 8 0}$ & $\mathbf{7 8 8}$ \\
\hline
\end{tabular}

The Exchange Rate used was US $\$ 1 \equiv$ D47.45, accessed from www.cbg.gm on $1^{\text {st }}$ November, 2017. The monetary values of land in the coastal zone were valued at GMD 3, 000 per $\mathrm{m}^{2}$ of land in the coastal zone sourced from the Department of Lands and Surveys, Banjul.

\section{Buniadu Point to Barra Point (Coastal Cell 1)}

This coastal cell covers a $12 \mathrm{~km}$ area from Buniadu Point, the Senegal boundary to the rocky cliffs at Barra Point and to the ferry terminal. The land in most part of this coastal cell is underdeveloped and under relatively low agriculture pressure. There are no noteworthy financial, social or cultural resources in danger aside few eco-resort developments along the coast. The wetland and town of Kajata with its populace are far away from the drift with less risk of coastal erosion. However, the full length of the shoreline is experiencing slight disintegration from coastal erosion (Fig. 5), with significant threats at Buniadu Point as the shoreline realigns, given changing waterfront forms [43].

This coastal unit requires less adaptation as the beachfront can naturally be restored with the enforcement of regulations governing land use planning and sand-mining operations. Other key structures to be protected at all cost should be relocated to hinterland and the reconstruction of such works elsewhere to avert threats from the impacts of SLR.

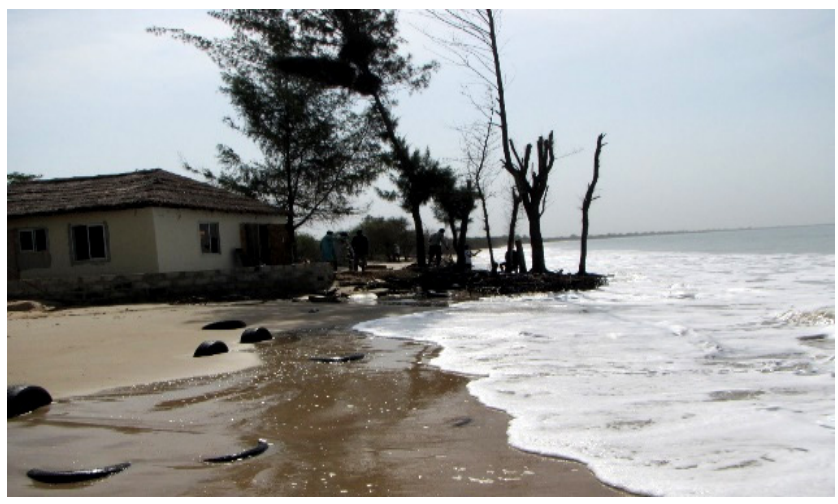

Figure 5. Some buildings at risk of coastal erosion. Source: NEA, 2016

\section{River Gambia Estuary (Coastal Cell 2)}

The river Gambia is approximately $11 \mathrm{~km}$ wide-ranging between Cape St. Mary and Buniadu Point and around 4 $\mathrm{km}$ wide between Banjul and Barra. It contracts down to almost $1.5 \mathrm{~km}$ at Carrol's Wharf. The river is flanked by an extensive mangrove system and mud flats providing substantial breeding and spawning support systems for aquatic species like fishes and shrimps. The dense mangrove systems also support the growth of oysters while the nearby low marshy lands are further used for rice cultivation; all serving as a means of livelihood for local community members $[41,44]$. 


\section{Banjul Port to Cape Point (Coastal Cell 3)}

This coastal cell has a $13.5 \mathrm{~km}$ stretch of land ranging from Banjul, the capital city of The Gambia to the Cape Point. Few people reside in this area as a considerable lot of the public and other institution workers ply this area daily for work engagements or as a transit point to other parts of the country. Some significant structures of economic, social or cultural benefit include the President's State House, The Gambia National Assembly, Ministry buildings, the national port, the Banjul Christian cemetery, Gambia National Museum, Banjul fish-landing site and hotels. The Ministry of foreign affairs building under construction is also located less than $300 \mathrm{~m}$ from the coastline. The lowest regions are as of now shielded from tidal flooding by a bund worked through the mangrove wetlands, yet they are liable to general coastal flooding amid summer storms owing to poor drainage. The beach nourishment exercise in 2004 was a short-term adaptation measure taken to protect structures like the highway and other valuable shorefront properties [45]. Other measures taken was the construction of the groyne system from the trunks of royal palm trees (Fig. 6A). The ' $T$ ' head groyne built immediately east of the Bakau fish-landing site has supported in sustaining a high tide beach along its western side (Fig. 6D). This notwithstanding, threats of destruction are being posed to infrastructure and businesses along the coast in recent times. For instance, the destruction of the Old Wharf at the Banjul port due to coastal erosion, wave action and other structures exposed to coastal erosion (Fig. 6B and 6C).

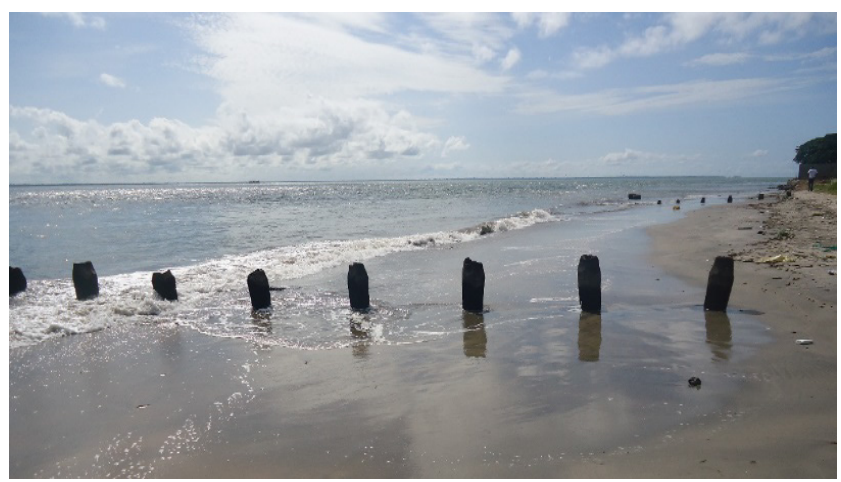

(A)

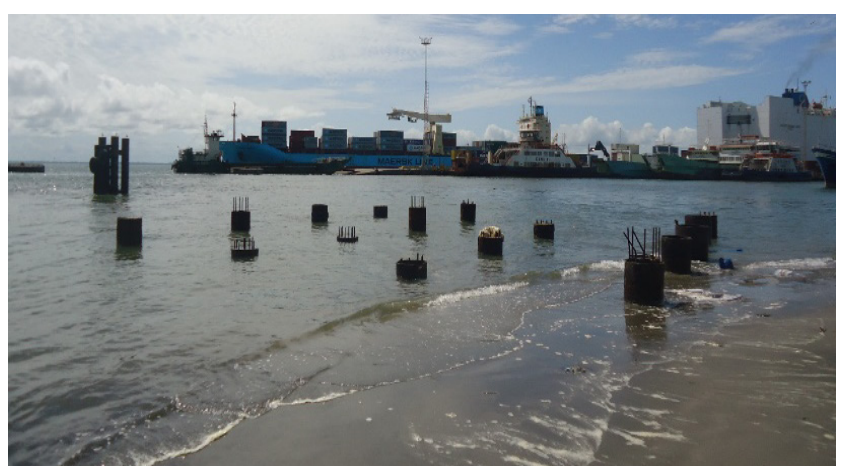

(B)

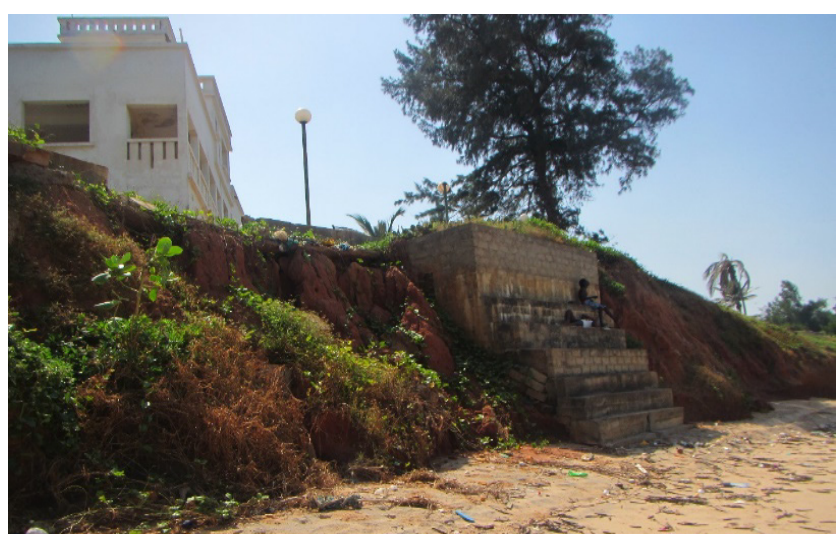

(C)

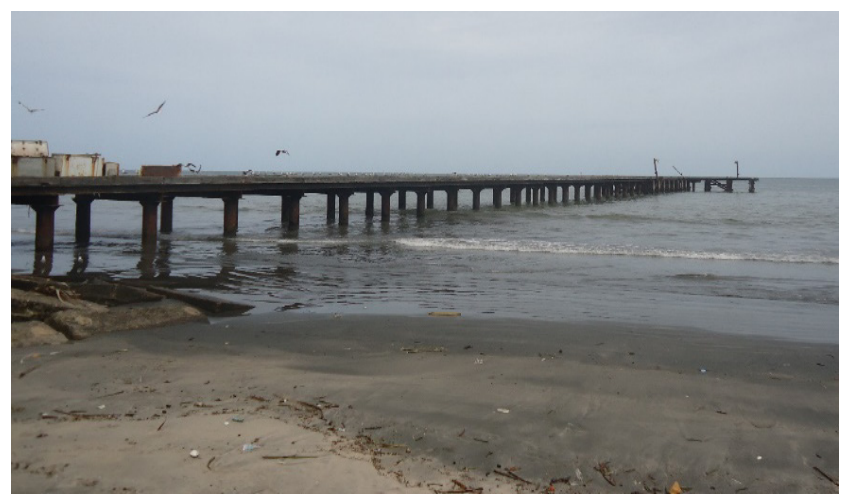

(D)

Figure 6. (A) Groyne system destroyed by coastal erosion and wave action. (B) Old Wharf destroyed by coastal erosion and wave action. (C) Some structures at Risk of Coastal Erosion. (D) The ' $\mathrm{T}$ ' Head Groyne Providing Sustenance of the Beach. Source: Author, 2017

A planned relocation should be done in the movement of government institutions and head-offices to areas with higher grounds above mean sea level to avert the threats of SLR. Constructing groyne systems will be more effective in protecting other key structures as compared to beach nourishment.

\section{Cape Point to Fajara (Coastal Cell 4)}

This coastal cell stretches over a distance of $3.5 \mathrm{~km}$. It is characterized by feebly dissolving bluffs and restricted pocket shorelines running west from Cape Point to the Ocean View Apartment complex. The upper layer of sandstone is liable to disintegration by stormwater spillover, and, where unprotected, the underlay is liable to disintegration by wave action. The precipices front a line of high esteem private properties, overseas organizations, consulates, some lower and mid-esteem tourism offices, the Bakau fish-landing site, among others. Besides threats of coastal erosion, this area is also prone to frequent flooding from the stream openings present in the area (Fig. 7A). There are other considerable damages to hotels, residential buildings along the shoreline of this coastal cell (Fig. 7C) besides the overtopping of a sea-wall constructed in the 1980s (Fig. 7B). 
Considering the impacts realized, there is the need for structural methods adopted to restore sediments already lost. Additionally, the study suggests that longitudinal coastal defence protective structures like seawalls, revetments and embankments be constructed to safeguard the shoreline from further direct wave action.

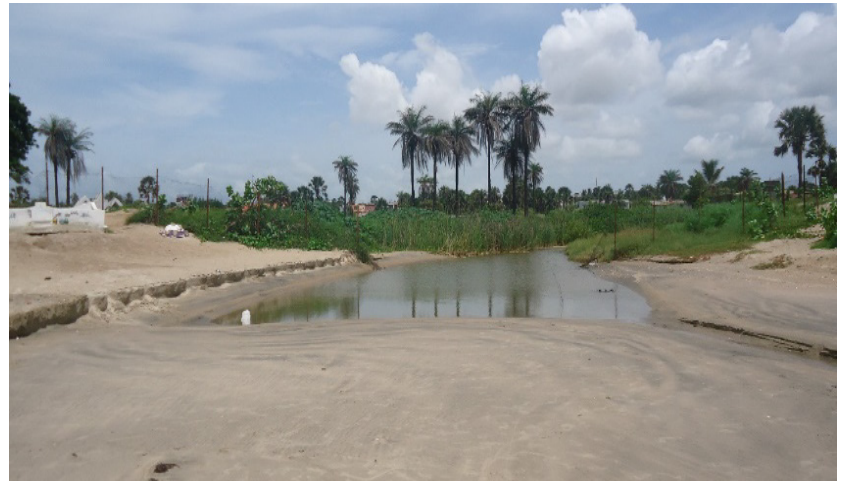

(A)

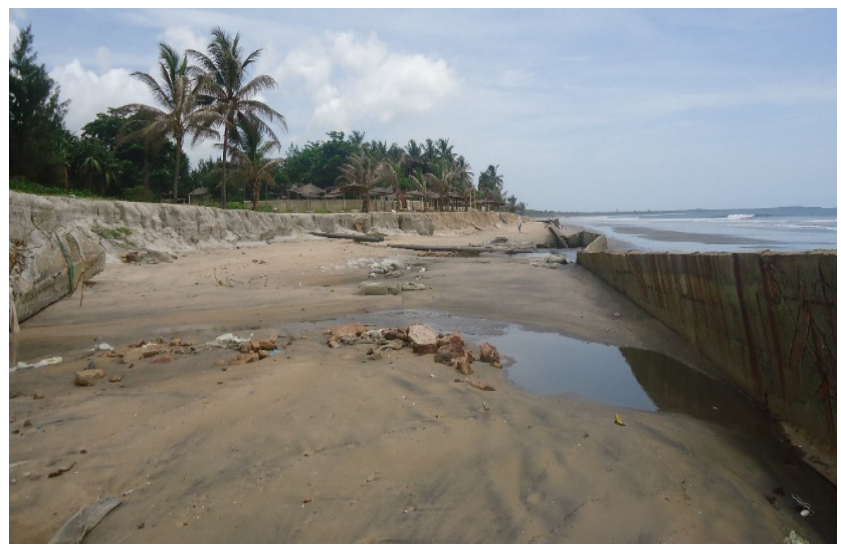

(B)

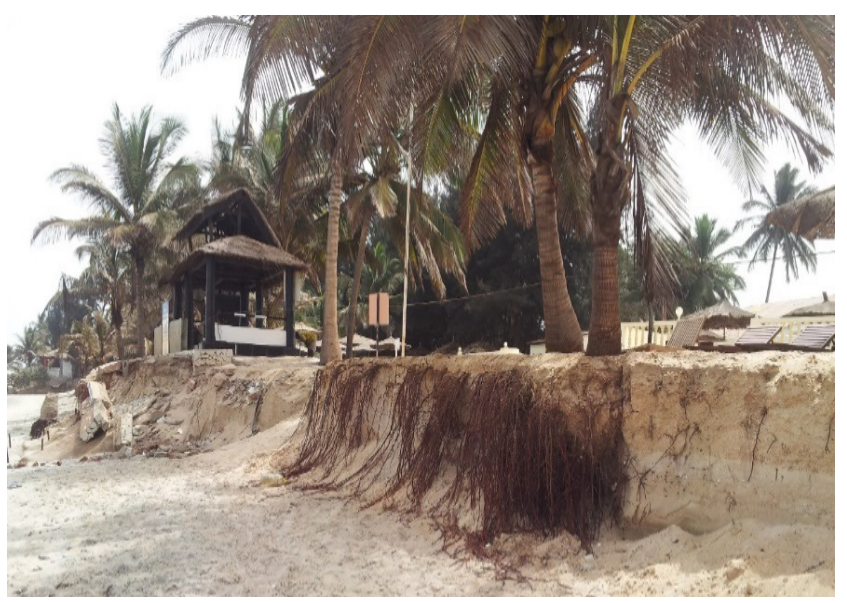

(C)

Figure 7. (A) The Opening of the Stream along the Coastal Cell. (B) Seawall Over-topped by increased wave action. (C) Some Structures at Risk of Coastal Erosion. Source: Author, 2017

\section{Kotu Point to Kololi Point (Coastal Cell 5)}

The shoreline of this coastal cell has a total span of 2.5 $\mathrm{km}$. It is wide and chiefly uninterrupted towards the north, while the southern part is narrow and mostly overdeveloped. Tourist-related infrastructure and the demarcated Tourist Development Area (TDA) mainly characterize this area. Beside coastal erosion that typifies this area, the shoreline is also susceptible to frequent river flooding from the ingress of the Kotu creek. Farmlands along Kotu Creek will probably experience the ill effects of prolonged flash floods and saline interruption, reducing the productivity of lands in this area in support of agricultural activities. Although there are embankments along some parts of the coastline, other areas are still exposed and likely to be at risk of coastal erosion in the short-term (Fig. 8).

Some of the adaptation measures that can be undertaken in this coastal unit are: beach nourishment using fine sand and its embankment for the stabilization of the shoreline. This can enhance tourism activities. It is imperative that prepared regulations regarding the TDA demarcation are strictly enforced to prevent the illegal development of infrastructure in this area that compromises the natural protection of the shoreline from coastal erosion.

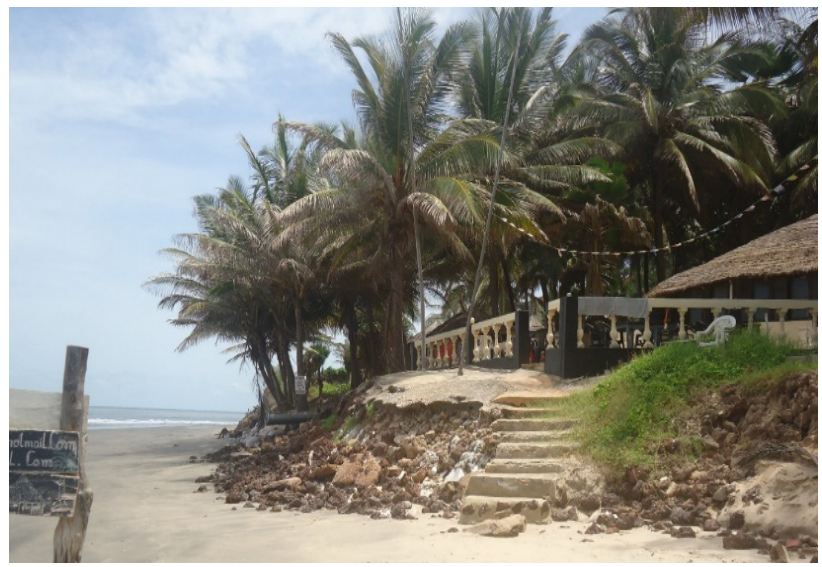

Figure 8. Some Structures at Risk of Coastal Erosion. Source: Author, 2017

\section{Kololi Point to Bald Cape (Coastal Cell 6)}

This coastal cell span $11 \mathrm{~km}$ from the Kololi point through Senegambia to Bald Cape. Many hotels, resorts and tourism infrastructure characterize this area similar to coastal cell 5. This area benefited from the beach nourishment in 2004 to safeguard key structures along the coast. During the beach nourishment, 1,000,000 $\mathrm{m}^{3}$ of sand was dredged from neighbouring Kololi Point with a placed 10 - 15 year life expectancy [14]. Bijl [14] argues that this life expectancy of the beach nourishment project was not reached as the beach returned to its original state after about 5 years leading to considerable regrets as approximately US $\$ 8,000,000$ was spent on this project. Without a positive administrative design, the shoreline 
will keep on deteriorating (Fig. 9A and 9B). This may force hotel and resort owners to undertake short-term and small-scale unsustainable interventions in safeguarding the shoreline in anticipation of attracting more affluent tourist and vacationers.

Some adaptation measures that can be untaken include beach-nourishment with fine sand and an embankment to safeguard the flow of sediment back into the ocean. Constructing breakwaters are needed to help reduce the impact of waves and storm surges on the coastline.

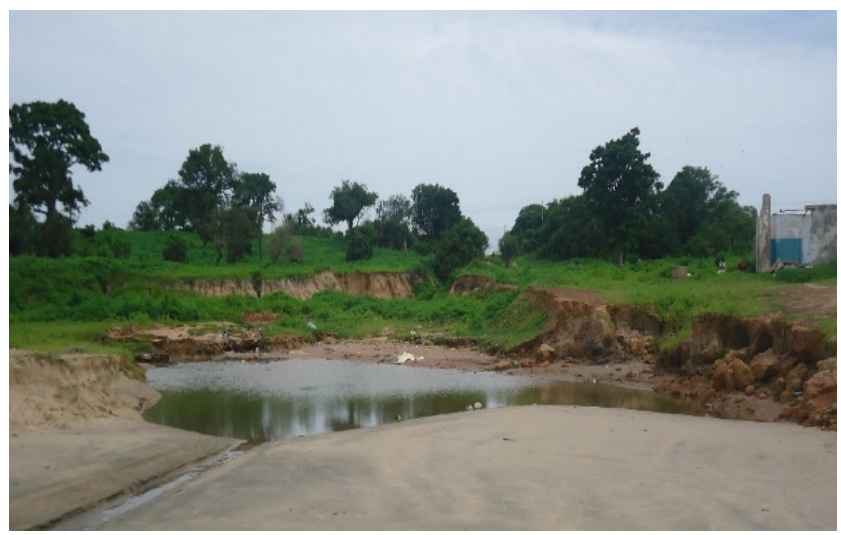

(A)

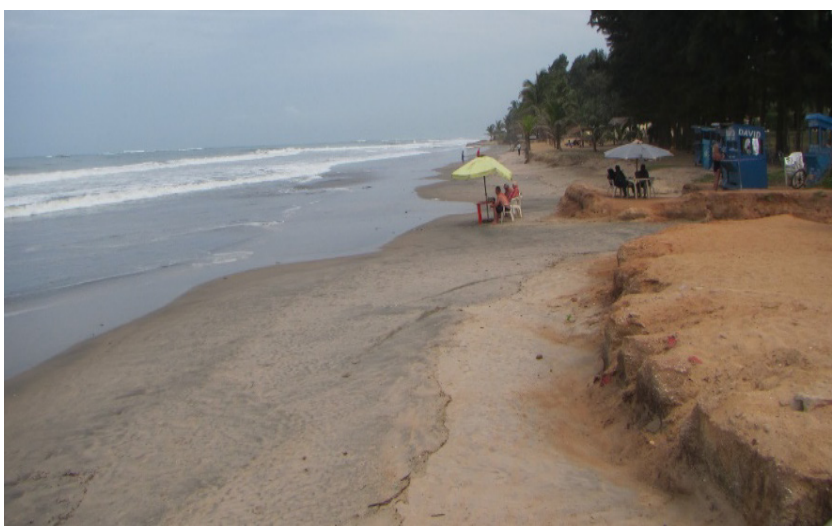

(B)

Figure 9. (A) Coastal Erosion along the Cell. (B) Eroding Cliffs along the coastline. Source: Author, 2017

\section{Bald Cape to Solifor Point (Coastal Cell 7)}

This cell spans $4.5 \mathrm{~km}$ from the Tanji fish-landing site in the South with its broad sandy shoreline to Solifor Point characterized by low laterite precipices. This area has few land used for agricultural purposes with several wind turbines for renewable energy generation. There are few structures at risk of coastal erosion with the fish-landing site the most predominant of them. This coastal unit requires less adaptation as the beachfront can naturally be restored with the enforcement of regulations governing land use planning and sand-mining operations.

\section{Solifor Point to Sanyang Point (Coastal Cell 8)}

This coastal cell extends $7.5 \mathrm{~km}$ from Solifor point to
Sanyang point where there are relatively low tourism and infrastructure developments. Generally, properties are well distant from the shoreline with less threat of destruction from coastal erosion in the short-term.

The study suggests the enforcement of regulations governing land use planning and sand-mining operations besides the relocation of structures to be protected at all cost hinterland.

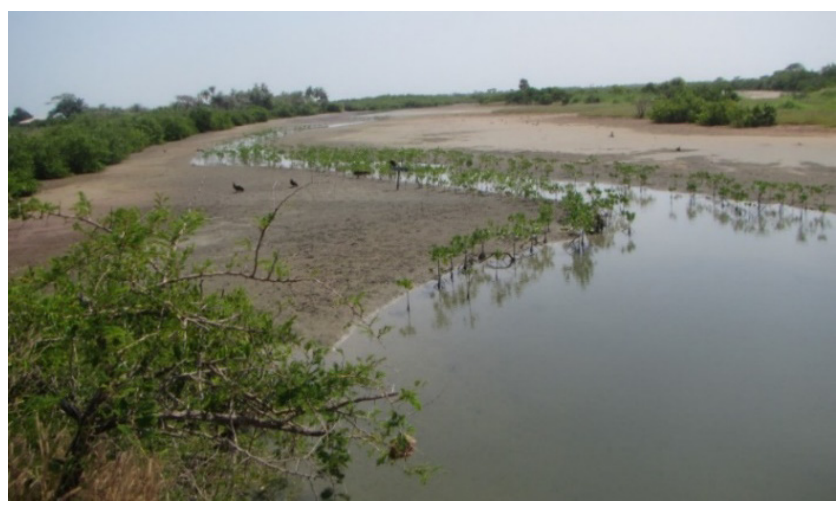

(A)

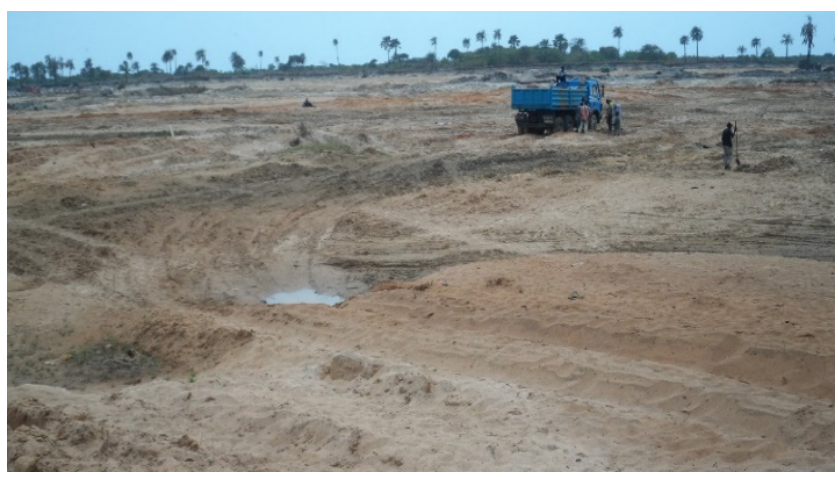

(B)

Figure 10. (A) Tidal Pond and Mangrove wetland around River Benifet. (B) Some Sand-mining activities in Karthong. Source: NEA, 2016

\section{Sanyang Point to Allahein River (Coastal Cell 9)}

This coastal cell extends over a distance of $24 \mathrm{~km}$ from Sanyang point to the Allahein River. The Southern part of Sanyang Point is characterized by an expansive fish-landing site supported by tidal ponds and mangrove wetlands at the convoluted mouth of the River Benifet (Fig. $10 \mathrm{~A})$. Past the stream mouth, the shoreline is undeveloped and sponsored by hills similarly to the headland at Bator Sateh where there is another extensive fish-landing site, vacation lodges and mangrove wetland. Most hotels and eco-resorts like the Sandele Eco-retreat, Nemasu Eco-lodge along the coast are distant from the shoreline posing less risk to the threats of coastal erosion. The sand mining operations in this area may likely expose this area to potential threats from SLR if a more sustainable approach is not adopted, as most land resources are being lost at an alarming rate (Fig. 10 B). This was realized during field visits to this site. 
The study recommends the adoption of a periodic rotation of sand mining sites to give a longer fallow period for the beach to restore naturally. In the worst affected areas in this coastal cell, stringent mining regulations should be engaged to ensure the transfer of mining activities to protective quarry sites hinterland to meet demand needs of the construction industry of The Gambia.

\subsection{Land Loss Due to Coastal Erosion}

Table 6 gives the results of estimation of the rate of coastal erosion along the coastline of The Gambia owing to a $1 \mathrm{~m}$ SLR scenario using the Bruun rule. This indicates the rate at which the land will be lost due to inundation along the coastal zone of The Gambia by the end of this century. The rate of coastal erosion along the entire coastline of The Gambia is estimated to be $\sim 6 \mathrm{~m}$ per year. The areas along Sanyang Point to the Allahein River (coastal cell 9) is estimated to have the highest rate of coastal erosion in the study area followed by areas covering Solifor Point to Sanyang Point (coastal cell 8); this corresponds to a respective value of around $2 \mathrm{~m}$ and $1 \mathrm{~m}$ per year. The areas of Banjul Port to Cape Point (coastal cell 3) recorded the least rate of coastal erosion of $0.14 \mathrm{~m}$ per year, followed by the $15 \mathrm{~m}$ per year value recorded for areas falling within Buniadu to Barra Point (coastal cell 1).

\subsection{Population at Risk of Coastal Flooding}

Table 7 shows the number of people at risk of coastal flooding events in the study area. The results show 15,560 people at risk of flooding events per $\mathrm{km}^{2}$ of land area. These people will be forced to migrate if apt adaptation strategies are not undertaken. The area from Kololi- Bald Cape (coastal cell 6) is estimated to have the largest number of people at risk of flooding followed by areas from Banjul Port to Cape Point (coastal cell 3); this corresponds to 6,249 and 2,955 per $\mathrm{km}^{2}$, respectively. The coastal cell with the least number of people exposed to flooding incidence due to surges in sea levels is cell 1 (Buniadu- Barra Point) with about 738 people per $\mathrm{km}^{2}$ of land area. The coastal cell 1 for instance, falls within the Northern region of The Gambia receiving relatively low amounts of rainfall to support rainfall-dependent agriculture and livestock activities in comparison with the other coastal areas [32]. This has led to the migration of people from the area in search of greener pastures southward [10]. This may explain why the area has the least population at risk of coastal erosion and flooding in the study area.

Table 6. Application of the Bruun Rule to project the rate of coastal erosion along the CZ of The Gambia due to Sea level rise.

\begin{tabular}{|c|c|c|c|c|c|c|}
\hline $\begin{array}{c}\text { Coastal } \\
\text { Cell }\end{array}$ & $\begin{array}{l}\text { Overfill } \\
\text { Ratio, G }\end{array}$ & $\begin{array}{c}\text { SLR Scenario, } \\
\text { S (m) } \\
\end{array}$ & $\begin{array}{l}\text { Active Profile } \\
\text { Width, W (m) }\end{array}$ & $\begin{array}{l}\text { Dune or Cliff } \\
\text { Height, H (m) }\end{array}$ & $\begin{array}{c}\text { Depth of Closure, } \\
d^{*}(\mathrm{~m})\end{array}$ & $\begin{array}{c}\text { Coastal Erosion Rate (Retreat), } \\
\quad \mathbf{R}=\mathbf{G} \times \mathbf{S}\left[\mathbf{W} /\left(\mathbf{H}+\mathbf{d}^{*}\right)\right],(\mathrm{m})\end{array}$ \\
\hline 1 & 1.0 & 1.0 & 100 & 1.2 & 5.3 & 15 \\
\hline 2 & - & - & - & - & - & - \\
\hline 3 & 1.0 & 1.0 & 180 & 1.7 & 10.7 & 14 \\
\hline 4 & 1.0 & 1.0 & 560 & 2.8 & 3.7 & 86 \\
\hline 5 & 1.0 & 1.0 & 400 & 1.6 & 6.3 & 50 \\
\hline 6 & 1.0 & 1.0 & 200 & 2.4 & 5.4 & 25 \\
\hline 7 & 1.0 & 1.0 & 130 & 0.7 & 0.7 & 92 \\
\hline 8 & 1.0 & 1.0 & 210 & 1.0 & 1.1 & 100 \\
\hline 9 & 1.0 & 1.0 & 680 & 1.5 & 1.6 & 219 \\
\hline \multicolumn{6}{|l|}{ Total } & 601 \\
\hline
\end{tabular}

Table 7. Estimation of Population at Risk of Coastal Flooding Events

\begin{tabular}{|c|c|c|c|}
\hline Coastal Cell & $\begin{array}{c}\text { Population Density (Number } \\
\text { per } \mathbf{k m}^{\mathbf{2}} \text { ) }\end{array}$ & $\begin{array}{c}\text { The probability of Coastal } \\
\text { Flooding Event }\end{array}$ & $\begin{array}{c}\text { The population at Risk of } \\
\text { Coastal Flooding }\end{array}$ \\
\hline 1 (Buniadu- Barra Point) & 2,461 & 0.3 & 738 \\
\hline 2 (River Gambia Estuary) & - & - & 2,955 \\
\hline 3 (Banjul Port- Cape Point) & 5,768 & 0.7 & 1,467 \\
\hline 4 (Cape Point- Fajara) & 2,933 & 0.5 & 927 \\
\hline 5 (Fajara- Kololi) & 4,634 & 0.2 & 6,249 \\
\hline 6 (Kololi- Bald Cape) & 15,623 & 0.4 & 1,033 \\
\hline 7 (Bald Cape- Solifor Point) & 1,148 & 0.9 & 1,023 \\
\hline 8 (Solifor Point- Sanyang Point) & 1,461 & 0.7 & 1,168 \\
\hline 9 (Sanyang Point- Allahein River) & 1,460 & 0.8 & $\mathbf{1 5 , 5 6 0}$ \\
\hline Total & & & \\
\hline
\end{tabular}




\section{Conclusions}

The observed increase in mean annual rainfall in the coastal zone of The Gambia over the past 30 years is likely to have positive implications for the natural restoration of some areas in the $\mathrm{CZ}$ of The Gambia. The observed increases in the annual maximum temperature is higher $(0.0276)$ than the decreases in the annual minimum temperatures (0.0255) in the coastal zone of The Gambia. This may have contributed to more warming than cooling events in the study area over the past 30 years. If this trend persists over the coming years, it may exacerbate the occurrence of SLR in the study area in the medium to long-term.

By the end of this century, under a $1 \mathrm{~m}$ SLR scenario, the total land to be lost due to inundation is $12.46 \mathrm{~km}^{2}(1,246$ ha) with a corresponding economic loss of $\sim$ US $\$ 788$ Million (GMD 37 Billion) over the coastal zone. This land loss along the coastline of The Gambia owing to the effects of coastal erosion is predicted to occur at an approximate rate of $6 \mathrm{~m}$ annually. The estimated total number of people at risk of being affected by coastal erosion and flooding events from SLR are 15,560 per $\mathrm{km}^{2}$ of land area. The areas ranging from Bald Cape to Solifor Point (coastal cell 7) had the largest area of land, $2.79 \mathrm{~km}^{2}$ to be lost under $1 \mathrm{~m}$ SLR scenarios with an estimated economic loss of US \$176.4 Million. The areas along Sanyang Point to the Allahein River (coastal cell 9) is estimated to possibly have the highest rate of coastal erosion with a value of $2 \mathrm{~m}$ each year under a $1 \mathrm{~m}$ SLR scenario. The areas of Kololi- Bald Cape (coastal cell 6) is recorded to have the largest number of people at risk of flooding followed by areas from Banjul Port to Cape Point (coastal cell 3); this corresponds to 6,249 and 2,955 respectively.

The adaptation measures recommended for each coastal cell are integrated into the results and discussion segment of this paper. The recommendations ranged from non-structural methods like the preparation, implementation and enforcement of regulations governing land use planning, and sand mining operations in the coastal zone, among others. Other structural adaptation methods recommended include the use of protective methods like constructing long longitudinal coastal defence structures like seawalls, embankments, besides active protection methods like constructing groyne and breakwater structures.

\section{Acknowledgements}

We are grateful to the West African Science Service Center on Climate Change and Adapted Land Use (WASCAL), the Government of Germany through the German Federal Ministry of Education and Research (BMBF) for the scholarship of JA and their financial contribution towards this research. JA is grateful to Mrs
Theresa Aniagyei-Bonsu for all her enormous support and motivation. Special thanks to the staff of the Department of Water Resources, Coastal and Marine Environment Unit of NEA, Department of Lands and Surveys, Gambia Bureau of Statistics for the data sourced from their respective institutions. We are also grateful to all other anonymous contributors to this work.

\section{REFERENCES}

[1] IPCC, Climate Change 2014-Impacts, Adaptation and Vulnerability: Regional Aspects. Cambridge University Press, 2014.

[2] C. A. Biney, G. Roberts, A. T. Amuzu, and R. R. Bannerman, "Coastal Zone Management in Accra, Ghana," in Coastlines of western Africa, 1993, pp. 114-128.

[3] M. Bollmann et al., "World Ocean Review 2010," Maribus Hambg. Ger., pp. 1-232, 2010.

[4] K. M. Brander, "Global fish production and climate change," Proc. Natl. Acad. Sci., vol. 104, no. 50, pp. 19709-19714, 2007.

[5] J. Cinner et al., "Social-ecological vulnerability of coral reef fisheries to climatic shocks," FAO Fish. Aquac. Circ. FAO Eng No 1082, pp. 1-15, 2013.

[6] GBoS, "Gambia Bureau of Statistics: 2013 Population and Housing Census. Directory of Settlements.," Gamb. Bur. Stat., pp. 1-83, 2013.

[7] M. C. Acreman, "Catchment Management Case StudySenegal River," Handb. Catchment Manag., pp. 1-377, 2010 .

[8] M. Elisa, J. I. Gara, and E. Wolanski, "A review of the water crisis in Tanzania's protected areas, with emphasis on the Katuma River-Lake Rukwa ecosystem," Ecohydrol. Hydrobiol., vol. 10, no. 2, pp. 153-165, 2010.

[9] B. Jongman, P. J. Ward, and J. C. Aerts, "Global exposure to river and coastal flooding: Long term trends and changes," Glob. Environ. Change, vol. 22, no. 4, pp. 823-835, 2012.

[10] National Climate Committee, "Second National Communication of the Republic of the Gambia to the United Nations Framework Convention on Climate Change," UNFCCC, pp. 1-163, 2013.

[11] NAPA, "The Gambia National Adaptation Programme of Action (NAPA) on Climate Change," Gov. Gamb. Banjul, 2007.

[12] B. P. Jallow, M. K. Barrow, and S. P. Leatherman, "Vulnerability of the coastal zone of The Gambia to sea level rise and development of response strategies and adaptation options," Clim. Res., pp. 165-177, 1996. 
[13] M. Lichter, A. T. Vafeidis, R. J. Nicholls, and G. Kaiser, "Exploring data-related uncertainties in analyses of land area and population in the 'Low-Elevation Coastal Zone'(LECZ)," J. Coast. Res., vol. 27, no. 4, pp. 757-768, 2010.

[14] E. Bijl, "The cause of coastal erosion on a nourished beach in Kololi, The Gambia," Delft Univ. MSc Thesis, pp. 1-153, 2011.

[15] UN-Habitat, "State of the world's cities 2008/2009: Harmonious cities," Earthscan Lond. 264pp, pp. 1-18, 2008.

[16] R. J. Nicholls, F. M. Hoozemans, and M. Marchand, "Increasing flood risk and wetland losses due to global sea-level rise: regional and global analyses," Glob. Environ. Change, vol. 9, pp. S69-S87, 1999.

[17] S. Brown, A. S. Kebede, and R. J. Nicholls, "Sea-level rise and impacts in Africa, 2000 to 2100," Sch. Civ. Eng. Environ. Univ. Southampt. UK, no. April, pp. 1-215, 2011.

[18] P. Bruun, "Sea-level rise as a cause of shore erosion," $J$. Waterw. Harb. Div., vol. 88, no. 1, pp. 117-132, 1962.

[19] A. Lüdeling and M. Kytö, "Vulnerability and Adaptations: An International Handbook (Vol. 1)," vol. 1, pp. 1-36, 1996.

[20] R. J. Nicholls and S. P. Leatherman, "The implications of accelerated sea-level rise for developing countries: a discussion," J. Coast. Res., pp. 303-323, 1995.

[21] R. G. Dean, "Equilibrium beach profiles: characteristics and applications," J. Coast. Res., vol. 1, no. 7, pp. 53-84, 1991.

[22] P. D. Komar et al., "The response of beaches to sea-level changes-a review of predictive models," J. Coast. Res., vol. 7, no. 3, pp. 895-921, 1991.

[23] T. Healy, "Sea level rise and impacts on nearshore sedimentation: an overview," Geol. Rundsch., vol. 85, no. 3, pp. 546-553, 1997.

[24] S. Corbella and D. D. Stretch, "Predicting coastal erosion trends using non-stationary statistics and process-based models," Coast. Eng., vol. 70, pp. 40-49, 2012.

[25] T. Aagaard and P. Sørensen, "Sea level rise and the sediment budget of an eroding barrier on the Danish North Sea coast," J. Coast. Res., vol. 65, no. sp1, pp. 434-439, 2013.

[26] P. Urquhart, "National Climate Change Policy of The Gambia Final Report: Final Draft Policy.," Gamb.-Eur. Union Coorporation, vol. 1, no. January, pp. 1-65, 2016.

[27] F. S. Fatajo, National issues report on key sector of agriculture (adaptation) in The Gambia, vol. August. 2010.

[28] FAO, "The FAO Component of the Sahel 2013 Humanitarian Appeals. Food and Agriculture Organization of the United Nation," Food Agric. Organ. United Nation, vol. 1, no. 1, pp. 1-62, 2013.

[29] S. Yaffa and A. Durand, "Climate change-induced loss and damage in The Gambia," Int. Cent. Clim. Change Dev., vol. 1, no. March, pp. 1-5, 2016.

[30] IFRC, "Hunger, disaster, hope: rethinking humanitarian action in Africa Advocacy report.," Int. Fed. Red Cross Red Crescent Soc., pp. 1-24, 2009.

[31] M. S. Jaiteh and B. Sarr, "Climate change and development in Gambia. Challenges to eco system goods and services," Gov. Gamb. 44pp, vol. 1, pp. 1-57, 2010.

[32] S. Yaffa, "Coping measures not enough to avoid loss and damage from drought in the North Bank Region of The Gambia," Int. J. Glob. Warm., vol. 5, no. 4, pp. 467-482, 2013.

[33] P. Hutchinson, "Rainfall analysis of the Sahelian drought in the Gambia," Int. J. Climatol., vol. 5, no. 6, pp. 665-672, 1985.

[34] ActionAid, "Drought in The Gambia as West Africa's Sahel crisis spreads," ActionAid UK, 2012. [Online]. Available: https://www.actionaid.org.uk/news-and-views/drought-in-t he-gambia-as-west-africas-sahel-crisis-spreads. [Accessed: 08-Dec-2017].

[35] E. R. Mohamed, "Impacts and Implications of Climate Change for the Coastal Zones of Egypt. Delta," pp. 31-50, 2010 .

[36] R. Gommes and F. Petrassi, "Rainfall variability and drought in sub-Saharan Africa," Environ. Nat. Resour. Serv., vol. 1, no. 106 , pp. 347-396, 1996.

[37] G. CRACP, "Vulnerability, Risk Reduction, and Adaptation to Climate Change, Sri Lanka," Wash. DC World Bank Group, pp. 1-16, 2011.

[38] Z. Nouaceur and O. Murărescu, "Rainfall Variability and Trend Analysis of Annual Rainfall in North Africa," Int. J. Atmospheric Sci., vol. 2005, pp. 50-72, 2016.

[39] L. M. Touray and K. Jammeh, "Drought conditions and management strategies in the Gambia.," Dep. Water Resour., pp. 1-7, 2013.

[40] F. P. Lima and D. S. Wethey, "Three decades of high-resolution coastal sea surface temperatures reveal more than warming," Nat. Commun., vol. 3, p. 704, 2012.

[41] MOA, "The Republic of The Gambia Agriculture and Natural Resources (ANR) Policy (2009- 2015)," Dep. Agric. Repub. Gamb., vol. July, no. 1, pp. 1-98, 2015.

[42] B. P. Jallow and M. K. A. Barrow, Vulnerability and adaptation assessment for the coastal resources sector, 3549. GOTG-USCP, 1997.

[43] T. Coates and A. Manneh, "GCCA Support Project to The Gambia for Integrated Coastal Zone Management and the Mainstreaming of Climate Change: Coastal Adaptation Scenarios Feasibility Scoping Report Prepared," Natl. Environ. Agency, vol. November, pp. 1-33, 2014.

[44] DPWM, "The National Biodiversity Strategy and Action 
Plan (2015- 2020). The Republic of the Gambia," Dep. Parks Wildl. Manag., pp. 1-118, 2015.

[45] Royal Haskoning, "Coastal Zone Management Handbook. Prepared for the NEA. The Government of The Gambia.,"
Natl. Environ. Agency Gov. Gamb., pp. 1-24, 2004.

[46] GBoS, "Gambia Bureau of Statistics: 2017 Annual Report." Gamb. Bur. Stat., pp. 1-83, 2017. 